\title{
Synthesis and Structure of New Compounds NSAIDs-Like Using a Heterogeneous Recyclable Catalyst
}

\author{
Anas Alkayal ${ }^{1}$, Mohammad Keshe ${ }^{1}$, Rushdi Madwar ${ }^{1}$, \\ Dikran Sarko ${ }^{2}$, Ayman Karam ${ }^{3, a}$
}

${ }^{1}$ Department of Chemistry, Faculty of Sciences, University of Al- Baath Homs, Syria.

${ }^{2}$ Faculty of Pharmacy, University of Al- Baath Homs, Syria.

${ }^{3}$ Institut de Chimie des Milieux et Matériaux de Poitiers, CNRS, Université de Poitiers/ENSIP, 1 rue Marcel Doré, 86073 Poitiers Cedex, France.

aE-mail: ayman.karam@univ-poitiers.fr.

Keywords: o-arylation, aryl ether synthesis, copper (I) catalyst, heterogeneous catalyst, NSAIDs.

\begin{abstract}
In this research, Phenol derivatives have been reacted with aryl halides using $5 \mathrm{~mol} \%$ $\mathrm{Cu}(\mathrm{I})$ Complex $[\mathrm{CuClPPh}]_{4}$ as catalyst supported on Amberlyst A21. The typical reaction has been performed between $p$-cresol and bromobenzene. This reaction is achieved in $o$-xylene as solvent. However, the catalyst complex does not dissolve in $o$-xylene rather it acts as heterogeneous catalyst. Therefore, it is filtrated at the end of the reaction and reused several times. Accordingly, new compounds were prepared by reacting some of bromoaryl derivatives with some Phenol derivatives. It is anticipated that the synthesized compounds have a structure NSAIDs-likes that may find their applications in the pharmaceutical industries.
\end{abstract}

\section{INTRODUCTION}

An aryl ethers have a medicinal importance [1], some derivatives are considered non-steroid anti-inflammatory [2], such as fenclofenac [3], which is considerd from diclofenac group and has similar pharmacological properties as anti-arthritis [4].<smiles>O=C(O)Cc1ccccc1Nc1c(Cl)cccc1Cl</smiles>

Diclofenace<smiles>O=C(O)Cc1ccccc1Oc1ccc(Cl)cc1Cl</smiles>

Fenclofenace

Figure 1. Structures of some aryl ethers which have a pharmacological active.

There are several ways to synthesis of aryl ethers is typically achieved via a nucleophilic aromatic substitution (NAS) process or transition metal catalyzed Ullmann-type $[5,6]$ and Hartwig $[7,8]$ or Buchwald-type [9,10] O-arylation reactions. The NAS approach requires the use of phenoxide to displace aryl fluorides or chlorides that are activated by strong electron withdrawing groups $(E W G)$ located in the ortho, para, or, in rare cases, meta positions. The requirement of the presence of an EWG is a severe limitation on the variety of aryl ethers available through NAS chemistry. In contrast, the transition metal catalyzed O-arylation reactions of phenoxides with aryl halides typically do not require the presence of an EWG and the reactions are highly efficient with aryl iodides and bromides.

Due to the high costs associated with palladium based catalyst systems, the past decade has seen the development of a multitude of copper catalysts for Ullmann-type O-arylation reactions $[11,12,13,14]$ and the area has been thoroughly reviewed $[15,16]$.

The effectiveness of these catalyst systems for the synthesis of aryl ether bonds is highly dependent on the substrate, ligand, solvent, base, and reaction temperature. During the course of a recent investigation of poly(arylene ether) synthesis, it became necessary to prepare a variety of 
asymmetric diaryl ether monomers and we chose to take advantage of the versatility of O-arylation reactions. Copper catalyzed O-arylation reactions are typically carried out in polar, aprotic solvents, however, given the requirement to utilize non-polar solvents, the use of toluene and xylene was explored. There are limited reports of $\mathrm{Cu}$-catalyzed $\mathrm{O}$-arylation reactions being performed in toluene or xylene $[14,15]$.

Development of efficient and practical catalysts for organic transformation to synthesize valuable target compounds is one of the most important research areas (academic and industrial) [17,18], Although homogeneous catalysts are finding applications in diverse aspects of synthetic chemistry [19], in recent years, the environmental concerns associated with their toxicity and disposal and catalyst/product separation are limiting their applications in general.

To that end, a variety of reaction conditions was studied in order to evaluate the effects of base, solvent and reaction temperature. This reaction has been realized in eco-friendly method.

\section{EXPERIMENTAL}

\subsection{Apparatus}

Spectrum NMR proton and carbon device $400 \mathrm{MHz}$ model Bruker by Switzerland company, optical absorption spectrum infrared device model FT-IR-4100 from the Japanese company Jasco.

\subsection{Reagents and materials}

Chlorine copper (II) dual hydrate, triphenyl phosphine, Para cresol, bromobenzene, paracetamol, ethanol, n-hexane, ethyl acetate, acetonitrile, $o$-xylene from BDH, 1-bromo-2,6dichloro benzene, Amberlyst A21 from Sigma Aldrich.

\section{EXPERIMENTAL PROCEDURE}

\section{Tetrakis-[chlorotriphenylphosphinecopper(I)] $\left[\mathrm{CuCIPPh}_{3}\right]_{4}$}

Was obtained by a slightly modified literature procedure [20], In a $100 \mathrm{~mL}$ round-bottomed flask were placed $1.71 \mathrm{~g}$ (10 mmol) of copper (II) chloride dihydrate and $90 \mathrm{~mL}$ of ethanol. The resulting mixture was heated to reflux and $3.93 \mathrm{~g}(15 \mathrm{mmol})$ of triphenyl phosphine was added in small portions. After complete addition, the mixture was maintained at reflux for 30 minutes. After cooling to room temperature, the resulting white solids were collected by filtration to afford $3.60 \mathrm{~g}$ ( $88 \%$ yield) of product, $\mathrm{mp} 240{ }^{\circ} \mathrm{C}$ ).

\section{General procedure for the synthesis of aromatic ethers}

$(2 \mathrm{mmol})$ aromatic bromide, $(3 \mathrm{mmol})$ phenol, $(0.1 \mathrm{mmol})$ catalyst, $(4 \mathrm{mmol})$ base, $(0.1 \mathrm{mmol})$ Amberlyst A21 and $(5 \mathrm{~mL})$ solvent were added to a $(100 \mathrm{~mL})$ three necked round-bottomed flask equipped with a Teflon stir bar, reflux condenser and nitrogen inlet. The flask was purged with nitrogen for 10 minutes before being immersed into an oil bath that was preheated to $140{ }^{\circ} \mathrm{C}$. The reaction mixture was allowed to stir at $140{ }^{\circ} \mathrm{C}$ for 24 hours. After cooling to room temperature, $(50$ $\mathrm{mL}$ ) of hexane were added and the mixture was allowed to stir for 1 hour at which point the mixture was filtered to get out the catalyst which coordinate to Amberlyst A21..

A filtrate was taken and the solvents were removed via rotary evaporation to provide a colorless oil, which was purified via column chromatography (silica gel) using (hexane: ethyl acetate)(1:1) as the eluent. The final product was obtained after removing the hexane and drying under vacuum.

\section{CHARECTARIZATION}

1-methyl,4-phenoxybenzene (Ph1). (41.60\%) was obtained as a colorless oil. IR spectrum (v, $\left.\mathrm{cm}^{-1}\right): 1240\left(\mathrm{C}_{\mathrm{sp} 2}-\mathrm{O}\right), 1495,1583(\mathrm{C}=\mathrm{C}), 2919\left(\mathrm{C}_{\mathrm{SP} 3}-\mathrm{H}\right), 3050\left(\mathrm{C}_{\mathrm{SP} 2}-\mathrm{H}\right) .{ }^{1} \mathrm{H}-\mathrm{NMR}\left(400 \mathrm{MHz}, \mathrm{CDCl}_{3}\right.$, $\delta, \mathrm{ppm}): 2.26\left(3 \mathrm{H}, \mathrm{S}, \mathrm{CH}_{3}\right), 6.84\left(2 \mathrm{H}, \mathrm{d}, \mathrm{J}=8.4 \mathrm{~Hz}, \mathrm{C}_{\mathrm{Ar}}-\mathrm{H}\right), 6.9\left(2 \mathrm{H}, \mathrm{d}, \mathrm{J}=8 \mathrm{~Hz}, \mathrm{C}_{\mathrm{Ar}}-\mathrm{H}\right), 6.99(2 \mathrm{H}, \mathrm{t}$, $\left.\mathrm{J}=7.6 \mathrm{~Hz} \mathrm{C}_{\mathrm{Ar}}-\mathrm{H}\right), 7.07\left(2 \mathrm{H}, \mathrm{d}, \mathrm{J}=8 \mathrm{~Hz}, \mathrm{C}_{\mathrm{Ar}}-\mathrm{H}\right), 7.24\left(1 \mathrm{H}, \mathrm{t}, \mathrm{J}=7.6 \mathrm{~Hz} \mathrm{C}_{\mathrm{Ar}}-\mathrm{H}\right) .{ }^{13} \mathrm{C}-\mathrm{NMR}(75 \mathrm{MHz}$, $\left.\mathrm{CDCl}_{3}, \delta, \mathrm{ppm}\right)$ : C-1 20.73, aromatic. C (118.35, 119.14, 122.8, 129.65, 130.24, 132.9, 154.71, 157.82). 
N-(4-(2,6-dichlorophenoxy)phenyl)acetamide (Ph2). (46.74\%) was obtained as a white solid, mp 182-184 ${ }^{\circ} \mathrm{C}$. IR spectrum (v, cm $\left.{ }^{-1}\right): 1258\left(\mathrm{C}_{\mathrm{sp} 2}-\mathrm{O}\right), 1373\left(\mathrm{CH}_{3}\right.$ bent $), 1640(\mathrm{C}=\mathrm{C}), 1738(\mathrm{C}=\mathrm{O})$, 2920, $2851\left(\mathrm{C}_{\mathrm{SP} 3}-\mathrm{H}\right), 3453(\mathrm{~N}-\mathrm{H}) .{ }^{1} \mathrm{H}-\mathrm{NMR}\left(400 \mathrm{MHz}, \mathrm{CDCl}_{3}, \delta, \mathrm{ppm}\right): 2.09\left(3 \mathrm{H}, \mathrm{S}, \mathrm{CH}_{3}\right), 6.72$ $\left(2 \mathrm{H}, \mathrm{d}, \mathrm{J}=9.2 \mathrm{~Hz}, \mathrm{C}_{\mathrm{Ar}}-\mathrm{H}\right), 7.08\left(1 \mathrm{H}, \mathrm{t}, \mathrm{J}=8.4 \mathrm{~Hz}, \mathrm{C}_{\mathrm{Ar}} \mathrm{H}\right), 7.34\left(2 \mathrm{H}, \mathrm{m}, \mathrm{C}_{\mathrm{Ar}}-\mathrm{H}\right), 7.34\left(2 \mathrm{H}, \mathrm{m}, \mathrm{C}_{\mathrm{Ar}}-\mathrm{H}\right)$, $7.04\left(1 \mathrm{H}, \mathrm{S}, \mathrm{C}_{\mathrm{Ar}} \mathrm{H}\right) .{ }^{13} \mathrm{C}-\mathrm{NMR}\left(75 \mathrm{MHz}, \mathrm{CDCl}_{3}, \delta\right.$, ppm): $\mathrm{C}-1$ 21.56, aromatic. $\mathrm{C}(119,123.15$, $126.95,129.37,130.41,132.48,144.24,151.83,170.84)$.

N,N'-(4,4'-(3-chloro-1,2-phenylene)bis(oxy)bis(4,1-phenylene))diacetamide (Ph3). (10.2\% was obtained as a white solid, mp 202-204 ${ }^{\circ} \mathrm{C}$. IR spectrum $\left(\mathrm{v}, \mathrm{cm}^{-1}\right): 1377\left(\mathrm{CH}_{3}\right.$ bent $), 1432,1629$ $(\mathrm{C}=\mathrm{C}), 1742(\mathrm{C}=\mathrm{O}), 2925,2858\left(\mathrm{C}_{\mathrm{SP} 3}-\mathrm{H}\right), 3427,3321(\mathrm{~N}-\mathrm{H}) .{ }^{1} \mathrm{H}-\mathrm{NMR}\left(400 \mathrm{MHz}, \mathrm{CDCl}_{3}, \delta, \mathrm{ppm}\right)$ : $2.11\left(3 \mathrm{H}, \mathrm{S}, \mathrm{CH}_{3}\right), 2.22\left(3 \mathrm{H}, \mathrm{S}, \mathrm{CH}_{3}\right), 6.97\left(2 \mathrm{H}, \mathrm{td}, \mathrm{J}=8 \mathrm{~Hz}, \mathrm{C}_{\mathrm{Ar}}-\mathrm{H}\right), 6.97\left(2 \mathrm{H}, \mathrm{td}, \mathrm{J}=8 \mathrm{~Hz}, \mathrm{C}_{\mathrm{Ar}}-\mathrm{H}\right)$, $7.08\left(1 \mathrm{H}, \mathrm{t}, \mathrm{J}=8.4 \mathrm{~Hz}, \mathrm{C}_{\mathrm{Ar}}-\mathrm{H}\right), 7.32\left(2 \mathrm{H}, \mathrm{q}, \mathrm{J}=8 \mathrm{~Hz}, \mathrm{C}_{\mathrm{Ar}} \mathrm{H}\right), 7.44\left(4 \mathrm{H}, \mathrm{d}, \mathrm{J}=9.2 \mathrm{~Hz}, \mathrm{C}_{\mathrm{Ar}}-\mathrm{H}\right) .{ }^{13} \mathrm{C}-\mathrm{NMR}$ $\left(75 \mathrm{MHz}, \mathrm{CDCl}_{3}, \delta, \mathrm{ppm}\right)$ : $\mathrm{C}-1$ 23.01, 25.43 aromatic. $\mathrm{C}(116.6,117.62,117.97,118.66,119.35$, $126.26,127.99,130.75,131.78,132.83,138.72,143.87,148.37,149.75,169.43,170.43)$.

2-(2,6-dichlorophenoxy)benzoic acid (D). (28.7\%) was obtained as a white solid, mp 143-145 ${ }^{\circ} \mathrm{C}$. IR spectrum $\left(\mathrm{v}, \mathrm{cm}^{-1}\right): 1241\left(\mathrm{C}_{\mathrm{sp} 2}-\mathrm{O}\right), 1375\left(\mathrm{C}_{\mathrm{sp} 2}-\mathrm{Cl}\right), 1632(\mathrm{C}=\mathrm{C}), 1752(\mathrm{C}=\mathrm{O}), 3452,(\mathrm{O}-\mathrm{H}) .{ }^{1} \mathrm{H}-$ NMR (400MHz, $\left.\mathrm{CDCl}_{3}, \delta, \mathrm{ppm}\right): 7.01\left(1 \mathrm{H}, \mathrm{t}, \mathrm{J}=7.6 \mathrm{~Hz}, \mathrm{C}_{\mathrm{Ar}}-\mathrm{H}\right), 7.48\left(2 \mathrm{H}, \mathrm{d}, \mathrm{J}=7.2 \mathrm{~Hz}, \mathrm{C}_{\mathrm{Ar}}-\mathrm{H}\right), 7.59$ $\left(1 \mathrm{H}, \mathrm{dd}, \mathrm{J}=5.2 \mathrm{~Hz}, \mathrm{C}_{\mathrm{Ar}}-\mathrm{H}\right), 7.3\left(1 \mathrm{H}, \mathrm{td}, \mathrm{J}=9.8 \mathrm{~Hz}, \mathrm{C}_{\mathrm{Ar}}-\mathrm{H}\right), 7.4\left(2 \mathrm{H}, \mathrm{td}, \mathrm{J}=7.6 \mathrm{~Hz}, \mathrm{C}_{\mathrm{Ar}}-\mathrm{H}\right) .{ }^{13} \mathrm{C}-\mathrm{NMR}$ $\left(75 \mathrm{MHz}, \mathrm{CDCl}_{3}, \delta, \mathrm{ppm}\right): \mathrm{C}-1170.34(-\mathrm{COOH})$ aromatic. $\mathrm{C}(117.27,120.31,122.88,126.69$, $128.69,132.31,133.88,134.78,151.49,161.14)$.

\section{RESULTS AND DISCUSSION}

The optimal conditions of preparations of 1-methyl-4-phenoxybenzene by etherification of p-cresol and bromobenzene have been studied

$$
\begin{aligned}
& \mathrm{Ar}-\mathrm{Br}+\mathrm{Ar}_{1}-\mathrm{OH} \underset{\mathrm{CuClPPh}_{3}, \text { Amberlyst-21 }}{\stackrel{\text { base, } o \text {-xylene, } 140^{\circ} \mathrm{C}}{\longrightarrow}} \mathrm{Ar} \longrightarrow \mathrm{O}-\mathrm{Ar}_{1} \\
& \mathrm{Ar}_{1}=\mathrm{C}_{6} \mathrm{H}_{5^{-}}, p-\mathrm{CH}_{3} \mathrm{C}_{6} \mathrm{H}_{4^{-}} \\
& \mathrm{ArBr}=\mathrm{C}_{6} \mathrm{H}_{5} \mathrm{Br} \text {, }
\end{aligned}
$$

Scheme 1. Coupling reaction of halide aryls and phenols via eco-friendly method.

Table 1. Results of $\left[\mathrm{CuClPPh}_{3}\right]_{4}$ catalyzed Ullmann coupling reaction of halide aryls with various phenols at $140^{\circ} \mathrm{C}$ for 24 hours.

Entry Aryl bromides


b-2-II

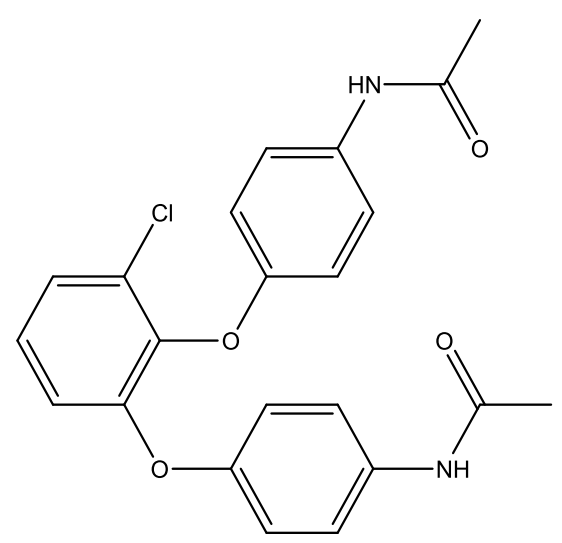

c-2
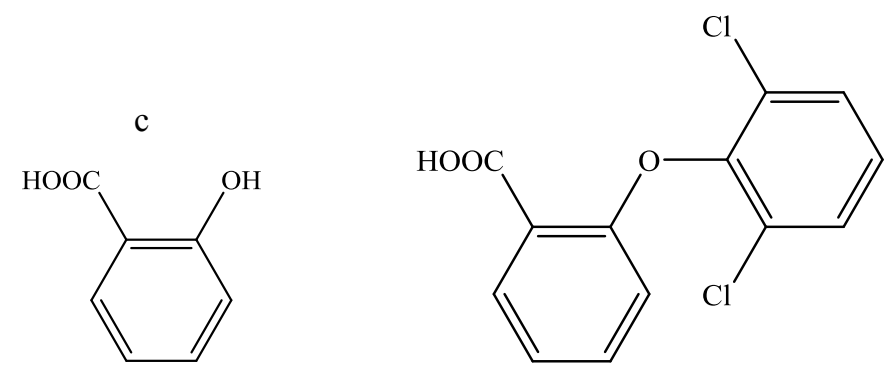

144

The presence of EDGs on the phenoxide typically improve the yields while the presence of EWGs hampered the reaction as shown in table 1 .

The complex which adsorbed on Amberlyst A21 has been recycled four times without significant lost in the yield, as shown in table 2, in comparing with the obtained yield of every cycle. Figure 2 shows the suggested structure of the adsorbed complex on Amberlyst A21

Table 2. Effect of complex adsorption on Amberlyst A21 on the yield

\begin{tabular}{ccccc}
\hline Entry & Product & $\begin{array}{c}\text { Yield\% } \\
\text { with* } \\
\text { Amberlyst } \\
\text { A221 }\end{array}$ & $\begin{array}{c}\text { without } \\
\text { Amberlyst }\end{array}$ & Base \\
\hline 1 & $1, \mathrm{a}$ & 41.6 & 31.6 & $\mathrm{~K}_{2} \mathrm{CO}_{3}$ \\
2 & $1, \mathrm{a}$ & 41 & 22.5 & $\mathrm{~K}_{2} \mathrm{CO}_{3}$ \\
3 & $1, \mathrm{a}$ & 38 & 2.5 & $\mathrm{~K}_{2} \mathrm{CO}_{3}$ \\
4 & $1, \mathrm{a}$ & 36 & 0 & $\mathrm{~K}_{2} \mathrm{CO}_{3}$ \\
5 & $1, \mathrm{a}$ & 22 & 0 & $\mathrm{~K}_{2} \mathrm{CO}_{3}$ \\
\hline
\end{tabular}

$*$ complex $\left[\mathrm{CuPPh}_{3} \mathrm{Cl}\right]_{4}$ adsorbing on Amberlyst A21.

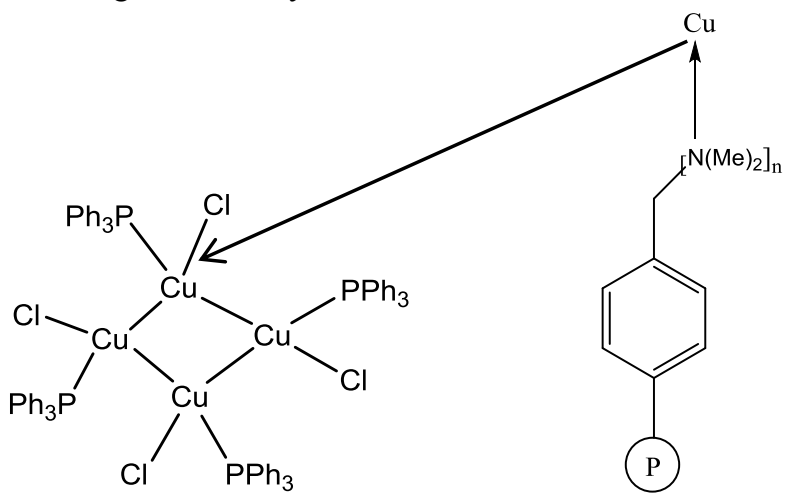

Figure 2. Complex $\left[\mathrm{CuPPh}{ }_{3} \mathrm{Cl}\right]_{4}$ adsorbing on Amberlyst A21. 
When the complex was used without adding Amberlyst A21, the complex decomposed in the next cycle as shown in table 2 (the yield was decrease from $31.6 \%$ in the first cycle to $22.5 \%$ in the second cycle and to $2.5 \%$ In the third cycle). These results could be explained that the complex was coordinated with the Amberlyst A21 [21], as shown in figure 2, and, in consequence, prevent of it degradation allowing to catalyze the reaction for four times, but in the fifth cycle, we observed a decrease in the yield of the ether that may be due to the leaching of the $\left[\mathrm{CuPPh}_{3} \mathrm{Cl}\right]_{4}$ from the surface of Amberlyst A21.

The effect of solvent and of base were studied. However, sodium carbonate has the worst effect on the yield of 1-a in different solvents, in other hand, the best yield of also cesium carbonate, does not exceed $11 \%$ in best cases when using toluene as a solvent, while the best base was potassium carbonate when using $o$-xylene as a solvent as shown in table 3.

Table 3. The effect of catalyst on Ullmann coupling reaction of p-cresol and bromobenzene at $140^{\circ} \mathrm{C}$ for 24 hours.

\begin{tabular}{ccccc}
\hline Entry & Base & Solvent & Product & Yield\% \\
\hline 1 & & Toluene & & 0 \\
2 & $\mathrm{Na}_{2} \mathrm{CO}_{3}$ & $o$-xylene & $1, \mathrm{a}$ & 2 \\
3 & & 1 ,4-dioxane & & 0 \\
4 & & Toluene & $1, \mathrm{a}$ & 21.22 \\
5 & & $o$-xylene & & 41.60 \\
6 & $\mathrm{~K}_{2} \mathrm{CO}_{3}$ & 1 ,4-dioxane & & 0 \\
7 & & Toluene & 10.70 \\
8 & & $o$-xylene & 5.20 \\
9 & $\mathrm{Cs}_{2} \mathrm{CO}_{3}$ & 1,4 -dioxane & & 0 \\
\hline
\end{tabular}

The kinetic profil Ullmann coupling reaction of halide aryls with various phenols was realized to show the optimal time to have maximum yield as shown in table 4 and figure 3 .

Table 4. Yields of aryl ethers during the time.

\begin{tabular}{ccccccccc}
\hline & \multicolumn{7}{c}{ Yield (\%) } \\
\hline \multicolumn{2}{c}{ Time (h) } & $\mathbf{2}$ & $\mathbf{6}$ & $\mathbf{1 2}$ & $\mathbf{1 8}$ & $\mathbf{2 1}$ & $\mathbf{2 4}$ & $\mathbf{3 0}$ \\
\hline \multirow{3}{*}{ Product } & $\mathbf{a - 1}$ & 3 & 10 & 17 & 30 & 38 & 41.6 & 37.5 \\
& $\mathbf{b}-2^{*}$ & 3.5 & 7 & 11 & 35 & 40 & 46.7 & 27 \\
& $\mathbf{c - 2}$ & 0 & 5.8 & 14 & 19 & 21 & 28.7 & 8
\end{tabular}

\footnotetext{
* b-2 is the sum of yields b-2-I and b-2-II
} 


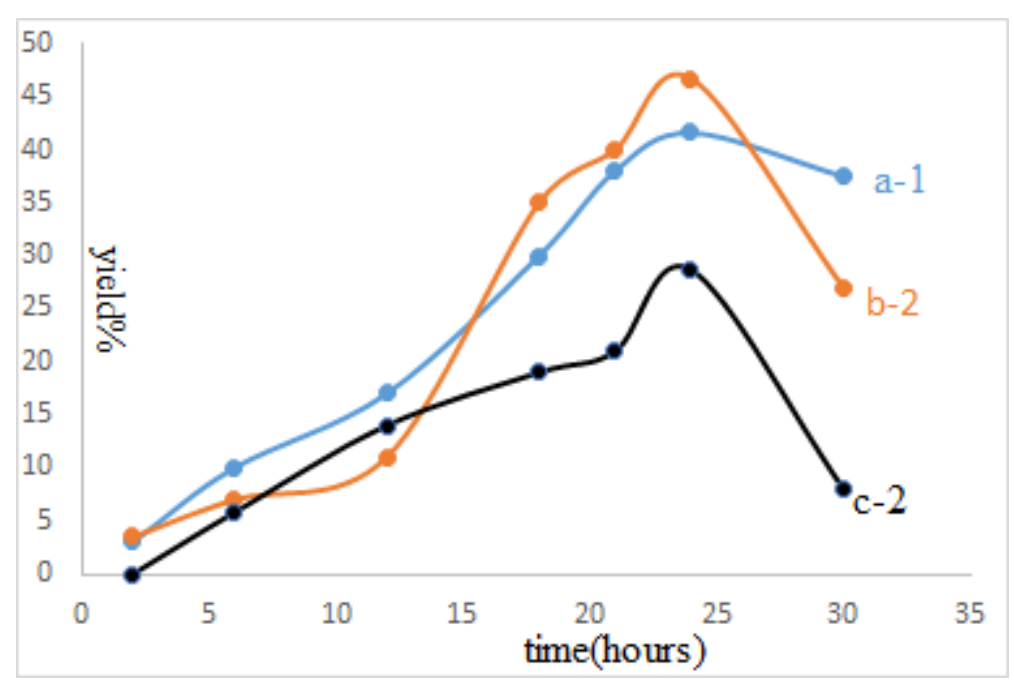

Figure 3. Kinetic profiles of preparation of aryl ethers.

Note that the best time to carry out the reaction is about 21-24 hours, Then after this time the compounds start to degrade and the yields decrease.

\section{CONCLUSION}

In summary some phenol derivatives have been interacted with some of aryl halides via ecofriendly method which has been mediated heterogeneous in the presence of complex $\left[\mathrm{CuPPh}{ }_{3} \mathrm{Cl}\right]_{4}$, the complex was adsorbed on Amberlyst A21 in $o$-xylene as solvent and in the presence of potassium carbonate as base. At end of the reaction, adsorbed complex on Ambyrlest A21 was filtered with potassium carbonate and reused four reaction cycle. Due to the cheap metal salt, the cheap base $\mathrm{K}_{2} \mathrm{CO}_{3}$ and the possibility of reusing the complex for several times in non-polar solvents such as $o$-xylenes, the yields (40-45\%) are acceptable. Prepared new compounds contain infrastructure of NSAIDs that may find their applications in the pharmaceutical industries.

\section{Acknowledgement}

The authors express their thanks to central laboratory in department of chemistry, AL Baath University, faculty of sciences, for their assistance during the work.

\section{References}

[1] D. Atkinson, K. Godfrey, B. Jordan, E. Leach, B. Meek, J. Nichols, J. Saville, 2-(2,4Dichlorophenoxy) phenylacetic acid (fenclofenac): one of a novel series of anti-inflammatory compounds with low ulcerogenic potential, J. Pharmacy and Pharmacology. 26 (1974) 357359.

[2] E. McNicol, S. Strassels, L. Goudas, J. Lau, D. Carr, NSAIDS or paracetamol, alone or combined with opioids, for cancer pain, Cochrane Database of Systematic Reviews. (2015).

[3] E. Spiers, N. Watson, J.S. Beck, I. Chapman, P. Dettmar, The effect of fenclofenac on the regeneration of lymphocytes in rats following total body irradiation, J. International Journal of Immunopharmacology. 15 (1993) 865-869.

[4] D.C. Atkinson, K.E. Godfrey, B. Meek, J.F. Saville, M.R. Stillings, J. Medicinal chemistry. 26 (1983) 1353-1360.

[5] D. Kikelj, R. Frlan, Recent Progress in Diaryl Ether Synthesis, J. Synthesis. 14 (2006) 22712285. 
[6] J. Scott Sawyer, Recent Advances in Diaryl Ether Synthesis, J. Tetrahedron. 56 (2000) 50455065.

[7] N. Kataoka, Q. Shelby, J. Stambuli, J. Hartwig, Air-Stable, Sterically Hindered Ferrocenyl Dialkylphosphines for Palladium-Catalyzed $\mathrm{C}-\mathrm{C}, \mathrm{C}-\mathrm{N}$, and $\mathrm{C}-\mathrm{O}$ Bond-Forming CrossCouplings, J. ChemInform. 34 (2003) 1-3.

[8] R. Gujadhur, C. Bates, D. Venkataraman, Formation of Aryl-Nitrogen, Aryl-Oxygen, and Aryl-Carbon Bonds Using Well-Defined Copper(I)-Based Catalysts, J. Org. Lett. 3 (2001) 4315-4317.

[9] Q. Shelby, N. Kataoka, G. Mann, J. Hartwig, Unusual in Situ Ligand Modification to Generate a Catalyst for Room Temperature Aromatic C-O Bond Formation, J. Am. Chem. Soc. 122 (2000) 10718-10719.

[10] J. Marcoux, S. Doye, S. Buchwald, A General Copper-Catalyzed Synthesis of Diaryl Ethers, J. Am. Chem. Soc. 119 (1997) 10539-10540.

[11] J. Chang, S. Chee, S. Mak, P. Buranaprasertsuk, W. Chavasiri, P. Chan, Copper-catalyzed Ullmann coupling under ligand- and additive- free conditions. Part 1: O-Arylation of phenols with aryl halides, J. Tetrahedron Letters. 49 (2008) 2018-2022.

[12] Z. Wang, X. Zhang, K. Sharpless, Asymmetric dihydroxylation of aryl allyl ethers, J. Tetrahedron Letters. 34 (1993) 2267-2270.

[13] A. Naidu, O. Raghunath, D. Prasad, G. Sekar, An efficient BINAM-copper(II) catalyzed Ullmann-type synthesis of diaryl ethers, J. Tetrahedron Letters. 49 (2008) 1057-1061.

[14] J. Niu, H. Zhou, Z. Li, J. Xu, S. Hu, An Efficient Ullmann-Type C-O Bond Formation Catalyzed by an Air-Stable Copper(I)-Bipyridyl Complex, J. Organic Chemistry. 73 (2008) 7814-7817.

[15] G. Evano, N. Blanchard, M. Toumi, Copper-Mediated Coupling Reactions and Their Applications in Natural Products and Designed Biomolecules Synthesis, J. Chemical Reviews. 108 (2008) 3054-3131.

[16] F. Monnier, M. Taillefer, Catalytic C-C, C-N, and C-O Ullmann-Type Coupling Reactions: Copper Makes a Difference, J. Angewandte Chemie International Edition. 47 (2008) 30963099.

[17] B. Cornils, Catalysis from A to Z. Weinheim: Wiley-VCH. (2007).

[18] R. Sheldon, I. Arends, U. Hanefeld, Green chemistry and catalysis. Weinheim: Wiley-VCH. (2007).

[19] P. Leeuwen, Homogeneous catalysis. Dordrecht: Kluwer Academic Publishers (2004).

[20] Yu. Z, Seng. T, Fossum. E, Aryl ether synthesis via Ullmann coupling in non-polar solvents: effect of ligand, counterion, and base, J. ARKIVOC. 14 (2009) 255-265.

[21] I. Jlalia, F. Meganem, J. Herscovici, C. Girard, "Flash" Solvent-free Synthesis of Triazoles Using a Supported Catalyst, J. Molecules. 14 (2009) 528-539. 